\title{
Drug use influence on mindfulness among nursing students
}

\author{
Influência do uso de drogas na atenção plena entre estudantes de enfermagem \\ Influencia del consumo de drogas en la atención plena entre los estudiantes de enfermería
}

'Universidade de São Paulo. Ribeirão Preto, São Paulo, Brazil.

Maycon Rogério Seleghim' ORCID: 0000-0001-8916-704X

Edilaine Cristina da Silva Gherardi-Donato' ORCID: 0000-0001-7475-6650

How to cite this article: Seleghim MR, Gherardi-Donato ECS. Drug use influence on mindfulness among nursing students. Rev Bras Enferm. 2019; 2020;73(1):e20170773. doi: http://dx.doi.org/10.1590/0034-7167-2017-0773

Corresponding Author: Maycon Rogério Seleghim E-mail: mseleghim@yahoo.com.br

EDITOR IN CHIEF: Antonio José de Almeida Filho ASSOCIATE EDITOR: Fátima Helena Espírito Santo

Submission: 12-02-2017

Approval: 06-11-2018

\section{ABSTRACT}

Objective: To assess the association between the presence of drug use and the dimensions of mindfulness in a population of students of technical education in nursing. Method: Correlational study conducted in a teaching institution in the inlands of the state of São Paulo, in 2017. Participants were 135 students for which the ASSIST questionnaire with personal characterization data and the Mindfulness Five-facet Questionnaire were applied. Data were analyzed with use of descriptive and analytical statistics. Results: The most used drugs were alcohol, tobacco and cannabis. The lowest score for mindfulness was 49 and the maximum was 171 points. There was a positive association between the presence of drugs in the three previous months and the "non-reactivity to internal experience" facet $(p=0.004)$. Conclusion: Although the association seems to be in line with the precepts of mindfulness, this fact cannot be considered positive if analyzed separately from the other concepts of mindfulness.

Descriptors: Mindfulness; Substance Use Disorders; Nursing Students; Technical Education in Nursing; Mental Health.

\section{RESUMO}

Objetivo: Verificar a associação da presença do uso de drogas com as dimensões da atenção plena em uma população de estudantes do ensino técnico em enfermagem. Método: Estudo correlacional, realizado em uma instituição de ensino do interior paulista, em 2017. Participaram 135 alunos para os quais foi aplicado o questionário ASSIST com dados de caracterização pessoal e o Questionário das Cinco Facetas do Mindfulness. Os dados foram submetidos à estatística descritiva e analítica. Resultados: As drogas mais utilizadas foram álcool, tabaco e maconha. O menor escore obtido para a atenção plena foi de 49 e o máximo de 171 pontos. Houve associação positiva entre a presença de drogas nos últimos três meses e a faceta "não reagir à experiência interna" $(p=0,004)$. Conclusão: Embora a associação pareça consonante com os preceitos do mindfulness, este dado não pode ser considerado positivo se analisado separadamente dos outros conceitos da atenção plena.

Descritores: Atenção Plena; Transtornos Relacionados ao Uso de Substâncias; Estudantes de Enfermagem; Educação Técnica em Enfermagem; Saúde Mental.

\section{RESUMEN}

Objetivo:Verificar la asociación entre la presencia del consumo de drogas y las dimensiones de la atención plena en una población de estudiantes de educación técnica de enfermería. Método: Investigación correlacional realizada en una institución de enseñanza en el interior de São Paulo, en 2017. Participación de 135 estudiantes para quienes se aplicó el cuestionario ASSIST con datos de caracterización personal y el cuestionario de cinco facetas de Mindfulness. Los datos se sometieron a estadísticas descriptivas y analíticas. Resultados: Las drogas más utilizadas fueron el alcohol, el tabaco y el cannabis. La puntuación más baja para mindfulness fue 49 y la máxima fue de 171 puntos. Hubo una asociación positiva entre la presencia de drogas en los últimos tres meses y la faceta "no reaccionar a la experiencia interna" ( $\mathrm{p}=0.004)$. Conclusión: Aunque la asociación parezca estar en línea con los preceptos de mindfulness, este hecho no puede considerarse positivo si se analiza por separado de otros conceptos de la atención plena.

Descriptores: Atención Plena; Trastornos por Uso de Sustancias; Estudiantes de Enfermería; Educación Técnica en Enfermería; Salud Mental. 


\section{INTRODUCTION}

Mindfulness has attracted the interest of researchers from various fields of knowledge due to its relevant effects on improvement of individuals' quality of life and wellbeing ${ }^{(1)}$. Although recognized and investigated internationally in recent decades, studies on this theme are scarce in Brazil.

In general, mindfulness can be defined as an inherent mental state of individuals and a disposition/personality trait that can be developed and/or refined by performing specific practices often found in intervention programs designed for this purpose ${ }^{(2-4)}$.

Some theoretical currents describe the central characteristics of the state of mindfulness ${ }^{(4)}$, but most agree that this state can be characterized by four main interconnected features or components ${ }^{(3-4)}$. The first is called non-elaborative and implies that people do not get caught in the automatic elaboration of the experience and its associations. Therefore, the intention is the conscious observation of thoughts and emotions provoked by experiences without the influence of situations lived previously.

The second component is the non-judgmental and related to people's ability to observe experiences without judgments rather than based on their belief systems and expectations acquired throughout life ${ }^{(3-4)}$. The third feature is called "centered on the here-and-now", in which individuals seek to analyze experiences with attention to the present moment, and not with reference to past moments ${ }^{(3-4)}$. Finally, the thoughts, feelings, and sensations arising in the attentional field are recognized and accepted as such by the subjects ${ }^{(3-4)}$.

In the academic scientific context, mindfulness-based practices originated with the work of Jon Kabat-Zinn, who introduced Buddhist meditation into Western clinical practice initially in the treatment of chronic pain and later in the treatment of anxiety disorders ${ }^{(3)}$. The positive results of practices is evidenced by their applicability in various fields and contexts ${ }^{(3-6)}$. Specifically with regard to stress, the mindfulness practice has shown promising results in individuals with high levels of stress response and favored the return of physiological parameters to baseline levels $s^{(7)}$.

On the other hand, some factors may act as modulators or interfere with mindfulness, for example, the use of drugs $s^{(1,5,8)}$. This has drawn attention from researchers in the area of mindfulness because it is considered a paradoxical aspect in determining this state ${ }^{(8)}$. In other words, drug use can be the interface with mindfulness from the moment that: 1) drug use can occur as a response or consequence to stress; and 2) drug use can induce/ provoke automatic or thoughtless behavior that can be regulated with the mindfulness practice.

As drug use is considered a potentially important factor in determining mindfulness, the aim of this study was to investigate the influence of this variable on the level of mindfulness of students of the technical course in nursing who have never performed exercises for improving this mental state.

This population was chosen because these future professionals constitute the largest team in the daily routine of health services and they are in direct contact with the clientele, family and community, which offers potential (well described in the literature) for the development of stress and drug use or abuse ${ }^{(9-11)}$. Until the development of this study, the scientific literature had no studies investigating the relationship of these variables in the area of nursing, and especially in technical courses.

\section{OBJECTIVE}

To assess the association between the presence of drug use and the dimensions of mindfulness in a population of students of a technical course in nursing.

\section{METHOD}

\section{Ethical aspects}

The project was approved by the educational institution and by the Human Research Ethics Committee.

Students were invited to participate in the study in person at the educational institution. They were also informed about the objectives of the study and the voluntary participation. The consent was expressed by signing the Informed Consent form (IC) in two copies. The researcher kept a copy and the other was given to the study participant.

\section{Design, place of study and period}

Cross-sectional, correlational study conducted in a private institution of technical education in nursing located in the inlands of the state of São Paulo, Brazil, during June 2017. The estimated population of the city is of 674,405 thousand inhabitants ${ }^{(12)}$. At the beginning of the study, the institution had 350 students enrolled, of which about 250 were in fact attending the course.

This institution was chosen intentionally because at the time of the study, it had the largest number of students of the technical course in nursing in the region and because of its academic-pedagogical partnership with the host institution of the present study.

\section{Sample and inclusion/exclusion criteria}

In this study, participants were 135 students (54\% of the total number of students attending the course) of both sexes aged 18 years and over, and present at the institution on the days of data collection. This was an intentional or convenience sample. There was loss of 115 (46\%) students, out of which 62 (24.8\%) refused to participate in the study and $53(21.2 \%)$ were developing internship practices in other cities in the region.

\section{Study protocol}

The following instruments were used in the study: a questionnaire with personal characterization variables prepared by the researchers themselves, the Alcohol, Tobacco and Substance Involvement Screening Test (ASSIST); and the Mindfulness Facets Questionnaire (Portuguese acronym: FFMQ-BR), both for use in the Brazilian population ${ }^{(13-14)}$.

The ASSIST instrument is a structured questionnaire containing eight questions about the use of nine classes of psychoactive substances (tobacco, alcohol, marijuana, cocaine, stimulants, sedatives, inhalants, hallucinogens, and opiates). The questions 
address the frequency of use in life and over the three previous months, use-related issues, concern about use by people close to the user, impaired performance of expected tasks, unsuccessful attempts to cease or reduce use, feeling of compulsion and use via injection.

Each response corresponds to a score that determines the degree of dependence (occasional use, indicative of abuse and suggestive of dependence) for each substance, ranges from 0 to 4 , and the total sum ranges from 0 to 20 . In this study, only scores indicating the presence of drug use in life and over the three previous months were considered, regardless of the type of drug used.

The purpose of the FFMQ is the multidimensional measurement of levels of mindfulness. It contains 39 questions and for each sentence, the respondent circles the answer that best describes the frequency of agreement, ranging from $1=$ never or rarely true to $5=$ almost always or always true. The concept of mindfulness of this scale is divided into five core components, namely: (1) Observing, which includes noticing or being aware of internal and external experiences such as sensations, cognitions, emotions, visions, sounds and smells; (2) Describing, which refers to the characterization of internal experiences through words; (3) Acting with awareness, which refers to being mindful of current activities and can be contrasted with mechanical behavior while attention is focused on something else (known as autopilot); (4) Non-judgment of the internal experience, which refers to not taking a posture of judgment and evaluation of thoughts and feelings; and (5) Non-reactivity to internal experience, which refers to the tendency to allow thoughts and feelings to come and go without being affected or taken over by them.

For the interpretation of the scale, the component "(2) Describing" is subdivided into two dimensions, "Describing - positive formulation" and "Describing - negative formulation" hence, there are six facets in total.

For data collection, the educational institution was asked to list all students enrolled according to the class number and period and inform the name of the teacher responsible for each class. With this information, the researcher contacted teachers individually and scheduled the day and time of the survey.

The subjects were approached according to the number of classes. First, the researcher explained to all students present in each class about the purpose, objectives and ethical aspects involved in the study. Those who agreed to participate in the study signed the IC form and received an opaque envelope containing the personal information questionnaire and the FFMQ, which was collected by the researcher on the following day. Some students preferred to leave the envelope at the course office. After that step, subjects were $2017(\mathrm{~N}=135)$ interviewed individually and in privacy to answer the questions of the ASSIST instrument, according to the application protocol of this instrument.

\section{Analysis of results and statistical}

The collected data were coded, tabulated and inserted in duplication in a Microsoft Excel 2010 spreadsheet. Data were exported to the Statistical Package for the Social Sciences ${ }^{\circ}$ (SPSS), version 24.0. Associations between the presence of drug use in life and in the three previous months and dimensions of mindfulness were tested by adopting a significance level of $5 \%$.

\section{RESULTS}

Most subjects were female (117 - 86.7\%), aged between 18 and 56 years old, and 89 (65.9\%) were aged between 18 and 29 years old. Almost half of the sample declared to be white (66 $48.9 \%$ ) and the other half declared to be mixed race (58-43.0\%). Most were single (66 - 48.9\%) and had no children (88-65.2\%).

Regarding the presence of drug use in life, alcohol (85-63.0\%), tobacco (41 - 30.4\%), and marijuana (33 - 24.5\%) were the most reported substances, followed less often by cocaine/crack and hypnotic/sedative drugs (11 - 8.2\% each). The characterization of drug use in the three previous months was like the use in life in relation to the three main drugs, since alcohol (71-52.6\%), tobacco (27 - 20.0\%) and marijuana (12-8.9\%) were also the most frequently reported substances.

Regarding the level of mindfulness, the lowest score was 49 and the highest was 171 points with an average of 109 points. Table 1 presents the score distribution according to the FFMQ dimensions. In general, the statistical analysis showed homogeneous results and participants achieved intermediate (or median) scores in each facet of mindfulness when considering the maximum and minimum scores of each one.

The association between the presence of drug use in life and in the three previous months with the facets of mindfulness is shown in table 2.

Only facet 6 - "non-reactivity to internal experience" was significant for drug use in the three previous months $(p=0.004)$. Drug use in life was not associated with facets or the FFMQ total score.

Table 1 - Population distribution according to the dimensions of mindfulness, Ribeirão Preto, São Paulo, Brazil,

\begin{tabular}{lccccc}
\hline \multicolumn{1}{c}{ Mindfulness facets } & Mean & Median & SD* & Minimum Maximum \\
\hline 1. Non-judgement of internal experience (max. 40 and min. 8) & 22.7 & 22.0 & 6.6 & 09 & 40 \\
2. Acting with awareness- autopilot (max. 25 and min. 5) & 10.3 & 10.0 & 3.7 & 05 & 23 \\
3. Observing (max. 35 and min. 7) & 25.7 & 25.0 & 6.9 & 10 & 40 \\
4. Describing - positive formulation (max. 25 and min. 5) & 15.6 & 16.0 & 4.7 & 05 & 25 \\
5. Describing - negative formulation (max. 15 and min. 3) & 7.3 & 7.0 & 2.7 & 03 & 15 \\
6. Non-reactivity to internal experience (max. 40 and min. 8) & 19.6 & 20.0 & 4.9 & 08 & 33 \\
7. Acting with awareness - distraction (max. 15 and min. 3 & 7.4 & 7.0 & 2.9 & 03 & 15 \\
Total & 109.0 & 106.0 & 20.9 & 49 & 171 \\
\hline
\end{tabular}


Table 2 - Population distribution according to the association between drug use in life and in the three previous months with the facets of mindfulness, Ribeirão Preto, São Paulo, Brazil, 2017 (N=135)

\begin{tabular}{|c|c|c|c|c|c|c|c|c|}
\hline \multirow{2}{*}{ Mindfulness facets } & \multicolumn{4}{|c|}{ Use in life } & \multicolumn{4}{|c|}{ Use in 3 previous months } \\
\hline & Minimum & Maximum & Median & $p^{*}$ & Minimum & Maximum & Median & $p^{*}$ \\
\hline 1. Non-judgement of internal experience (max. 40 and min. 8) & 09 & 40 & 23.0 & 0.279 & 09 & 40 & 23.0 & 0.973 \\
\hline 2. Acting with awareness- autopilot ( $\max .25$ and $\min .5$ ) & 05 & 23 & 10.0 & 0.905 & 05 & 23 & 10.0 & 0.561 \\
\hline 3. Observing (max. 35 and $\min .7$ ) & 11 & 40 & 26.0 & 0.268 & 11 & 40 & 25.0 & 0.689 \\
\hline 4. Describing - positive formulation ( $\max .25$ and $\min .5$ ) & 05 & 25 & 16.0 & 0.476 & 05 & 25 & 15.0 & 0.103 \\
\hline 5. Describing - negative formulation ( $\max .15$ and $\min .3$ ) & 03 & 15 & 7.0 & 0.632 & 03 & 15 & 7.0 & 0.471 \\
\hline 6. Non-reactivity to internal experience (max. 40 and $\min .8$ ) & 11 & 33 & 20.0 & 0.125 & 11 & 33 & 19.0 & 0.004 \\
\hline 7. Acting with awareness - distraction ( $\max .15$ and $\min .3$ ) & 03 & 15 & 7.0 & 0.778 & 03 & 15 & 6.0 & 0.376 \\
\hline Total & 69 & 171 & 106.0 & 0.860 & 69 & 171 & 105.0 & 0.328 \\
\hline
\end{tabular}

Note: *Mann-Whitney test

\section{DISCUSSION}

Despite the few studies conducted with students of technical courses in nursing, the personal characteristics of the sample were similar to those described in the literature, but divergent when considering particularly the available data regarding age, marital status and presence of children ${ }^{(15-17)}$.

Two studies that identified the profile of technical education students in Brazil are noteworthy. The first study was conducted in the city of Rio de Janeiro with 1,400 participants attending the technical course ${ }^{(16)}$. The sociodemographic characterization of students showed a predominantly female (85.7\%) group, the age of $65.6 \%$ of them was between 31 and 50 years old, and $51.5 \%$ were married and had children. The second study was conducted with graduates from a probabilistic sample of 215 participants distributed in cities of the state of São Paulo(17). Most respondents were married women with a mean age of 42.2 years.

Based on these studies, the present sample differed when considering that most participants were in the age range of 1829 years old, single and had no children. A possible explanation may be that the mentioned studies included individuals who already practiced the nursing profession and were seeking to complement education. Another reason can be broader structural social issues in terms of changes in the economic profile of Brazil, such as the increased demand for technical training professions resulting from the labor market needs.

Regarding the type of drugs used, data are similar to those of the general population and the university population, since alcohol, tobacco, and marijuana were the most reported substances, followed less frequently by cocaine/crack and hypnotic/ sedative drugs, both in use in life and use over the three previous months. The Home Survey on Psychotropic Drug Use II was the most recent and comprehensive epidemiological survey on drug use in Brazil. It was conducted in 2005 in the 108 largest cities in the country. In this study, the most commonly used drugs in life were alcohol first by $74.6 \%$ of the sample, followed by tobacco with $44.0 \%$ and marijuana with $8.8 \%{ }^{(18)}$.

Regarding the level of mindfulness, the sample presented an average of 109 points. Since there is no cutoff point for the interpretation of the FFMQ total score (sum of all questions -195 points), the level of mindfulness of the sample can be considered as regular. Despite the classification as regular in strictly numerical terms, because students in the sample have never performed exercises to train this mental state, these data could be understood as satisfactory.

Although the mindfulness facets had the same distribution of the FFMQ total score and presented median values, the association between the presence of drug use and the mindfulness dimensions showed that facet 6 - "non-reactivity to internal experience", was significant for drug use in the three previous months $(p=0.004)$. This facet refers to individuals' ability to remain unaffected or negatively affected by feelings and thoughts arising internally ${ }^{(19)}$.

The positive association between recent drug use and the ability to not react to internal experiences (consistent with a mindfulness posture) should be carefully analyzed. In mindfulness, unresponsiveness to inner experience is one of the characteristics that, coupled with the other aspects of mindfulness, allows subjects to move from the automatic mode to a conscious response $\mathrm{e}^{(14,19)}$.

Non-reactivity to internal experience alone should not be taken as positive or as corresponding to the mindfulness precepts in its entirety. The "high resolution" perception of thoughts and emotions as they arise is one of the steps, or part of the way from impulsivity to conscious response.

The positive association between drug use and the ability to not react to internal experience found in the investigated population cannot be considered as a positive result if analyzed separately from the other constructs that constitute the mindfulness "philosophy". In other words, the ability to not react to internal demands must be accompanied by other skills for real attainment of mindfulness, for example, by observation and non-judgment of experience ${ }^{(14,19)}$.

A possible consideration in the population in question is that non-reactivity to internal experiences caused by recent drug use could produce a posture unable to perceive and reflect on internal stimuli by acting or operating without reflection, which are well described behaviors in the literature on drug users ${ }^{(14,19)}$.

On the other hand, this association was similar to that found in a study of 944 college students in the United States, in which the FFMQ was used to measure mindfulness ${ }^{(19)}$. In such a study, non-reactivity was a moderately associated facet, among other things, to the lack of concentration or focus and to lower levels of intolerance to suffering. The more significant statistical association 
of this dimension with the presence of depressive symptoms, stress and problems with alcohol use is noteworthy.

This result is strengthened by the contents included in mindfulness-based programs for reducing and/or managing episodes of drug relapse, such as Mindfulness Based Relapse Prevention, which are focused on working the skills and behaviors of people so they do not react automatically to drugs, together with other concepts of mindfulness ${ }^{(5)}$.

Accordingly, in a study of 187 patients who sought treatment at a mood and anxiety disorders clinic in Connecticut in the United States, was found a statistically significant association of non-reactivity to internal experience with the presence of anxiety and depression symptoms ${ }^{(20)}$. The findings support associations between specific facets of mindfulness and highlight the potential utility of addressing these specific aspects in interventions for psychiatric disorders, such as drug addiction.

\section{Study limitations}

One of the limitations of this study was obtaining information on drug use through students' responses. Even offering privacy and comfort, this is a delicate issue because individuals may not have revealed the actual use of substances, especially because they are health professionals in training.

\section{Contributions to the nursing area, health or public policy}

The findings are relevant for the investigated population because certain psychological skills to deal with mechanisms of internal reactivity are essential for the nursing profession practice, especially considering the need for readiness in urgency/ emergency situations and in the establishment of therapeutic interpersonal bonds sustained by empathy and otherness.
Longitudinal studies should be conducted for a deeper understanding of the subject and to monitor the evolution of drug use in order to determine the levels of mindfulness and especially the internal reactivity.

\section{CONCLUSION}

The aim of this study was to find the association between the presence of drug use in life and in the three previous months and the dimensions of mindfulness in a population of students of a technical course in nursing. Although drug use was associated with non-reactivity to internal experiences, in line with a mindfulness posture, this fact cannot be considered positive if analyzed separately from the concepts of the other constructs that constitute mindfulness.

Considering the incipient qualification of many professionals in technical courses in nursing, few initiatives have included aspects other than the pedagogical, which are potentially relevant for the better performance and achievement during these students' training. This fact reinforces the relevance of results found in this study.

The education process of health workers is closely related to the quality of care that will be provided in the future. Hence the need for attention from competent bodies in the training and qualification of human resources in nursing, especially at the technical level. Furthermore, all determinants involved should be considered with a view to improving the quality of care provided by these future workers.

\section{FUNDING}

Conselho Nacional de Desenvolvimento Científico e Tecnológico (CNPq) Universal MCTI/CNPq 01/2016, process number 424062/2016-0.

\section{REFERENCES}

1. Keng SL, Smoski MJ, Robins CJ. Effects of mindfulness on psychological health: a review of empirical studies. Clin Psychol Rev. 2011;31(6):1041-56. doi: 10.1016/j.cpr.2011.04.006

2. Brown KW, Ryan, RM. Perils and promise in defining and measuring mindfulness: observations from experience. Clin Psychol (New York) [Internet]. 2004 [cited 2017 Jul 23];11(3):242-8. Available from: http://onlinelibrary.wiley.com/doi/10.1093/clipsy.bph078/abstract

3. Kabat-zinn J. Full catastrophe living: using the wisdom of your body and mind to face stress, pain, and illness. Dell Publishing; New York: 1990.

4. Pires JG. Instrumentos para avaliar o construto mindfulness: uma revisão. Aval Psicol [Internet]. 2015 [cited 2018 Mar 07];14(3):329-38. Available from: http://pepsic.bvsalud.org/pdf/avp/v14n3/v14n3a05.pdf

5. Witkiewitz K, Bowen S, Douglas H, Hsu SH. Mindfulness-based relapse prevention for substance craving. Addict Behav [Internet]. 2013 [cited 2017 Jul 23];38(2):1563-17. Available from: https://www.ncbi.nlm.nih.gov/pubmed/22534451

6. Mackenzie MB, Kocovski NL. Mindfulness-based cognitive therapy for depression: trends and developments. Psychol Res Behav Manag. 2016;9(1):125-32. doi: 10.2147/PRBM.S63949

7. Boyd JE, Lanius RA, Mckinnon MC. Mindfulness-based treatments for posttraumatic stress disorder: a review of the treatment literature and neurobiological evidence. J Psychiatry Neurosci. 2018;43(1):7-25. doi: http://doi.org/10.1503/jpn.170021

8. Bowen S, Enkema MC. Relationship between dispositional mindfulness and substance use: findings from a clinical sample. Addict Behav. 2014;39(3):532-537. doi: http://doi: 10.1016/j.addbeh.2013.10.026

9. Teixeira CAB, Gherardi-Donato ECS, Pereira SS, Cardoso L, Reisdorfer E. Occupational stress and coping strategies among nursing professionals in hospital environment. Enferm Glob [Internet]. 2016 [cited 2017 Jul 23];15(44):310-20. Available from: http://scielo.isciii.es/ pdf/eg/v15n44/en_administracion3.pdf 
10. Teixeira CAB. Occupational stress among nursing technicians and assistants: coping focused on the problem. Invest Educ Enferm [Internet]. 2015 [cited 2017 Jul 23];33(1):28-34. Available from: https://www.ncbi.nlm.nih.gov/pubmed/26148153

11. Reisdorfer E, Delziovo CR, Gherardi-Donato ECS, Moretti-Pires RO. Problematic alcohol and tobacco use among healthcare professionals. SMAD, Rev Eletrôn Saúde Mental Alcool Drog. [Internet]. 2016 [cited 2017 Jul 23];12(4):204-21. Available from: http://pepsic.bvsalud.org/ $\mathrm{pdf} / \mathrm{smad} / \mathrm{v} 12 \mathrm{n} 4 / \mathrm{pt} \_$04.pdf

12. Instituto Brasileiro de Geografia e Estatística. IBGE. Ribeirão Preto: população no último censo [Internet]. 2017 [cited 2017 Jul 23 ]. Available from: http://cidades.ibge.gov.br/xtras/perfil.php?codmun=354340

13. Henrique IFS, De Micheli D, Lacerda RB, Lacerda LA, Formigoni MLOS. Validação da versão brasileira do teste de triagem do envolvimento com álcool, cigarro e outras substâncias (ASSIST). AMB Rev Assoc Med Bras [Internet]. 2004 [cited 2017 Jul 23];50(2):1899-206. Available from: http://www.scielo.br/pdf/ramb/v50n2/20784.pdf

14. Barros VV, Kozasa EH, Souza ICW, Ronzani TM. Validity evidence of the Brazilian version of the Five Facet Mindfulness Questionnaire (FFMQ). Psicol Teor Pesqui[Internet]. 2014 [cited 2017 Jul 23];30(3):317-27. Available from: http://www.scielo.br/pdf/ptp/v30n3/09.pdf

15. Ximenes Neto FRG, Rocha J, Cunha ICKO. Auxiliares e técnicos de enfermagem na saúde da família: perfil sociodemográfico e necessidades de qualificação. Trab Educ Saúde[Internet]. 2008 [cited 2017 Jul 23];6(1):51-64. Available from: http://www.scielo.br/pdf/tes/v6n1/04.pdf

16. Oliveira BGRB, Porto IS, Ferreira MA, Castro JBA. Profile of students registered in nursing auxiliary and technician courses of the Nursing Worker Professionalization Project (Profae) in Rio de Janeiro - Brazil. Rev Latino-Am Enferm[Internet]. 2007 [cited 2017 Jul 23];15(1):127-33. Available from: http://www.scielo.br/pdf/rlae/v15n1/v15n1a19.pdf

17. Bógus CM, Bersusa AAS, Martins CL, Escuder ML. Conhecendo egressos do curso técnico de Enfermagem do PROFAE. Rev Esc Enferm USP [Internet]. 2011 [cited 2017 Jul 23];45(1):945-52. Available from: http://www.scielo.br/pdf/reeusp/v45n4/v45n4a22.pdf

18. Carlini EA. II levantamento domiciliar sobre o uso de drogaspsicotrópicas no Brasil: estudo envolvendo as 108 maiores cidades do país: 2005. CEBRID - Centro Brasileiro de Informações Sobre Drogas Psicotrópicas: UNIFESP - Universidade Federal de São Paulo. São Paulo: Páginas \& Letras;1-472, 2007.

19. Brown DB, Bravo AJ, Roos CR, Pearson MR. Five Facets of Mindfulness and psychological health: evaluating a psychological model of the mechanisms of mindfulness. Mindfulness [Internet]. 2015 [cited 2017 Jul 23];6(5):1021-32. Available from: https://www.ncbi.nlm.nih.gov/ pubmed/26504498

20. Desrosiers A, Klemanski DH, Nolen-Hoeksema S. Mapping mindfulness facets onto dimensions of anxiety and depression. Behav Ther [Internet]. 2013 [cited 2017 Jul 23];44(3):317-84. Available from: https://www.ncbi.nlm.nih.gov/pubmed/23768665 